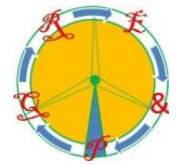

\title{
Potential fuel savings in a combined cycle in Egypt by integrating a parabolic trough solar power plant
}

\author{
Adham M. Abdelhalim ${ }^{1}$, Inés M. Suárez-Ramón ${ }^{2}$ \\ ${ }^{1}$ Department of Mechanical Engineering \\ Arab Academy for Science and Technology \\ Alexandria, Egypt \\ Phone: +201222219310, e-mail: adhammuhamed90@gmail.com \\ ${ }^{2}$ Energy Department \\ University of Oviedo \\ 33204 Gijon (Asturias) \\ Phone: +34 985182365, e-mail: ines@uniovi.es
}

\begin{abstract}
Energy is one of the most basic elements of the universe that is essential for all life processes. The problem facing the world nowadays is the diminishing of fossil fuel resources and the increasing of emissions to the atmosphere, thus world attention is now going to the utilizing of renewable energy sources. The aim of this paper is to evaluate the potential fuel savings that could be achieved by integrating a parabolic trough collector solar power plant into an existing natural gas combined cycle in the city of Alexandria, in Egypt, where direct solar radiation levels are high all year, varying from $2,000 \mathrm{kWh} / \mathrm{m}^{2}$ to $3,200 \mathrm{kWh} / \mathrm{m}^{2}$. The Integrated Solar Combined Cycle (ISCC) has been modelled in Matlab, using Simulink to couple a control system that simulates the operation of the hybrid plant under fuel saving mode. The results show that the tested system achieves good fuel saving, reaching 436,000 \$/year in case of controlling the amount of oil that passes in the parabolic collector and $165,625 \$$ year in case of not controlling the amount of oil with a percentage of $38 \%$ of the first case.
\end{abstract}

Key words. Integrated solar combined-cycle (ISCC), fuel saving control mode, parabolic trough collectors (PTC), solar radiation, heat transfer fluid.

\section{Introduction}

Energy is one of the key elements of the universe, necessary to do any work. The energy demands are closely linked to the economic growth of a country, as every home, every business, and every major issue is underpinned by energy. This is why global energy consumption has increased steadily for much of the twentieth century and will still increase to reach a $56 \%$ rise in the next three decades, driven by growth in developing countries such as China and India, as stated by the Energy Information Administration (EIA) [1]. As energy production has traditionally been directly linked to the carbon dioxide emissions because of the major use of fossil fuels, huge efforts are done nowadays to replace the carbon intense energy sources and thus reduce global warming emissions. In this direction, energy production technologies based on renewable sources have gained great interest, as they produce little to no global warming emissions, on a life-cycle basis [2].

Egypt is one of the most populous countries in Africa and the Middle East. With a 2019 estimated population of 101 million people, Egypt ranks $14^{\text {th }}$ among the highest populations in the world. During the last three decades, Egypt experienced a rapid economic growth, and although energy production increased since 1990, where it goes up from 55 Mtoe to 80 in 2018, this rise was not sufficient to cope up with the rapidly increase in the energy consumption that reached 90 Mtoe in 2018 [3]. To meet the fast growing electricity demand, the Egyptian Electricity Holding Company (EEHC) and its affiliated companies exert all their efforts to add annual achievements translated by energy projects including production, transmission and distribution of electricity [4].

Modern electricity generation involves multiple energy production technologies and those based on renewable sources play an important role. Among these technologies, solar thermal power plants are spreading widely, often combined with a storage system or being part of a hybrid plant that allows overcoming the periods without solar radiation.

Integrated Solar Combined Cycle Power Plants (ISCCs) are one of the most promising hybrid configurations. ISCCs are composed of a Concentrated Solar Power plant (CSP) and a Natural Gas-Fired Combined Cycle (NGCC). The CSP plant is normally used either to produce additional steam for use in the NGCC's steam turbine [5, $6]$, or to preheat the compressed air in the gas turbine before entering the combustion chamber [7]. Among the main four types of collectors that are used in CSP plants, Parabolic Trough Collectors (PTC) represent the most mature concentrated solar power technology. PTC are high thermal efficiency with high performance systems, and also light structure with low cost technology that can 
deliver up to $400{ }^{\circ} \mathrm{C}$, which is generally high enough for most of the industrial heating processes and applications.

ISCC have been intensively studied over the past 20 years. Most of the studies are focused on the evaluation and improvement of the ISCC efficiency, using different pressure level steam cycles, integration schemes or heat transfer fluids [8-10]. Some researchers have found that ISCCs are more efficient and profitable than standalone CSP and CC [11-12]. However, there is little work related to the control schemes or optimization strategies that make ISCCs more purposive when operating either to save fuel or to boost more power [13-14].

In this work a study of the fuel savings that could be reached integrating a parabolic trough collector power plant in an existing combined cycle in Alexandria, Egypt, is done. The solar field is integrated in the Rankine cycle to preheat the water before entering the economizer of the HRSG, and a control system maintains the net power output constant by adjusting both flow rates for gas and steam in the combined cycle without changing the total output power (fuel saving mode).

\section{Description of the installation}

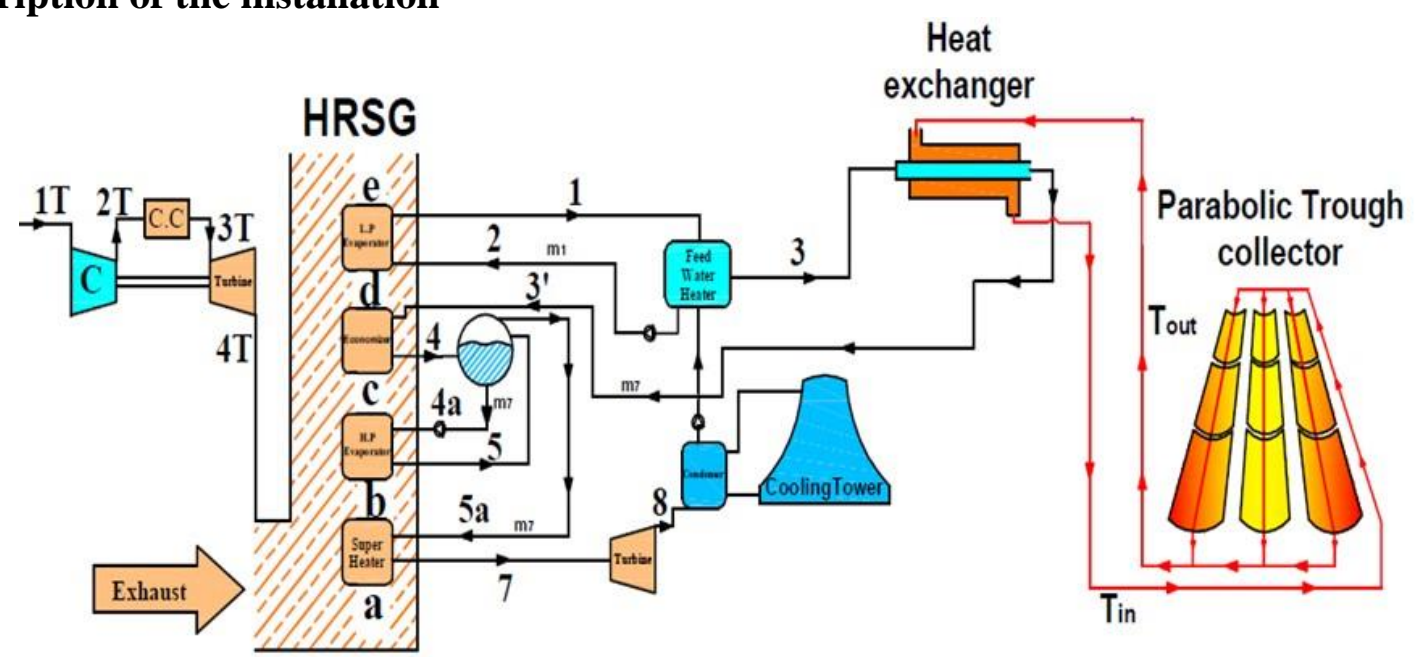

Fig. 1. Schematic diagram for the ISCC.
SEGS VI solar field occupies an area of $188 \mathrm{~km}^{2}$ and the net turbine capacity is $30 \mathrm{MW}$. PTCs of type LS-2 with single axis tracking are aligned in North-South direction and distributed in 50 loops of 16 collectors each. Table II summarizes the main characteristics of the collectors.

In this study, the solar field is integrated in the Rankine cycle in the HRSG economizer to produce additional steam that is mixed with the steam produced from the superheater. Water is withdrawn from the feedwater heater (at point 3) to be heated by the heat gained by the solar collector, where a heat exchanger is placed to transfer the heat absorbed by the HTF to the water. After being heated (at point 3'), it is passed to the economizer to complete its cycle in the HRSG until the steam production in the superheater.

\section{Model setup}

Figure 1 shows the schematic diagram of the proposed ISCC power plant, which consists of two main parts: an existing combined cycle and a new solar field.

\section{A The combined cycle}

At present, the combined cycle produces electricity for the Petrochemical Company in Alexandria, Egypt (latitude consists of a gas turbine, a steam turbine, and a heat recovery steam generator (HRSG) that links between the first two components. The gas turbine is of type "Gt8c" constructed by $\mathrm{ABB}$ with a rating of $55 \mathrm{MW}$, while the steam turbine is of type "DK-M 045" constructed by Brown, Boveri \& Compagnie (BBC) with a rating of 29 MW. The main characteristics of both turbines are given in Table I.

\section{B. The solar field}

The solar field data are taken from "SEGS VI", one of the nine plants that form the second largest solar concentrating thermal energy generating facility in the world, located in Califorma's Mojave Desert [15]. $31^{\circ} 12^{\prime} \mathrm{N}$, longitude $29^{\circ} 55^{\prime} \mathrm{E}$, altitude $18 \mathrm{~m}$ ). This cycle

\section{A. Solar plant}

The solar plant is composed by the solar field, where the solar radiation heats up the HTF, and the solar heat exchanger, where the energy gained by the HTF is transferred to the water of the Rankine cycle.

Energy balance on the solar field results in Eq. (1), where the energy gained by the HFT, $\dot{Q}_{\text {gain }}(\mathrm{W})$, is equal to the difference between the absorbed solar heat, $\dot{Q}_{a b s}(\mathrm{~W})$, and the heat losses to the ambient air, $\dot{Q}_{a m b}(\mathrm{~W})$ :

$\dot{Q}_{\text {gain }}=\dot{Q}_{a b s}-\dot{Q}_{a m b}$

The energy gained by the HTF can be expressed by Eq. (2) in terms of the mass flow rate of the fluid through the collectors, $\dot{m}_{H T F}(\mathrm{~kg} / \mathrm{s})$, the specific heat at constant pressure, $c_{p, H T F}\left(\mathrm{~J} / \mathrm{kg} \quad{ }^{\circ} \mathrm{C}\right)$, and the difference of 
temperature between the inlet and the outlet, $T_{\text {in }}$ and $T_{\text {out }}$ $\left({ }^{\circ} \mathrm{C}\right)$ :

$$
\dot{Q}_{\text {gain }}=\dot{m}_{H T F} c_{p, H T F}\left(T_{\text {in }}-T_{\text {out }}\right)
$$

Table I. - Technical data for the combined cycle

\begin{tabular}{|c|c|c|}
\hline \multirow{10}{*}{ Gas cycle } & \multicolumn{2}{|l|}{ Compressor } \\
\hline & Inlet Ambient temperature $\left({ }^{\circ} \mathrm{C}\right)$ & 24 \\
\hline & Inlet pressure (bar) & 1 \\
\hline & \multicolumn{2}{|l|}{ Combustion chamber } \\
\hline & Inlet pressure (bar) & 15.7 \\
\hline & Inlet temperature $\left({ }^{\circ} \mathrm{C}\right)$ & 379 \\
\hline & \multicolumn{2}{|l|}{ Turbine } \\
\hline & Inlet temperature $\left({ }^{\circ} \mathrm{C}\right)$ & 1100 \\
\hline & Exhaust temperature $\left({ }^{\circ} \mathrm{C}\right)$ & 540 \\
\hline & Exhaust mass flow rate $(\mathrm{kg} / \mathrm{s})$ & 184.7 \\
\hline \multirow{7}{*}{$\begin{array}{l}\text { Steam } \\
\text { cycle }\end{array}$} & Inlet steam pressure (bar) & 43 \\
\hline & LP evaporator pressure (bar) & 2.4 \\
\hline & Condenser pressure (bar) & 0.08 \\
\hline & Inlet steam temperature $\left({ }^{\circ} \mathrm{C}\right)$ & 441 \\
\hline & Economizer outlet temperature $\left({ }^{\circ} \mathrm{C}\right)$ & 240 \\
\hline & $\begin{array}{l}\text { Solar heat exchanger inlet } \\
\text { temperature }\left({ }^{\circ} \mathrm{C}\right)\end{array}$ & 127 \\
\hline & LP evaporator mass flow rate $(\mathrm{kg} / \mathrm{s})$ & 5 \\
\hline $\begin{array}{l}\text { Combined } \\
\text { cycle }\end{array}$ & Total power output (MW) & 83.9 \\
\hline
\end{tabular}

Table II. - Characteristics of the collectors

\begin{tabular}{|l|c|}
\hline \multicolumn{2}{|c|}{ Geometric and optical parameters } \\
\hline Aperture length $(\mathrm{m})$ & 50 \\
\hline Aperture width $(\mathrm{m})$ & 5 \\
\hline Shading factor & 1 \\
\hline Collector length (m) & 753.6 \\
\hline Total collector length (m) & 37,680 \\
\hline Concentration ratio & 70 \\
\hline Mirror reflectance & 0.94 \\
\hline Receiver absorptivity & 0.94 \\
\hline Mirror transmittance & 0.915 \\
\hline Absorber pipe diameter $(\mathrm{m})$ & 0.066 \\
\hline \multicolumn{2}{|c|}{ Heat transfer fluid $($ HTF $)$} \\
\hline HTF & Terminol VP-1 \\
\hline HTF inlet temperature $\left({ }^{\circ} \mathrm{C}\right)$ & 135.5 \\
\hline HTF flow rate $(\mathrm{kg} / \mathrm{s})$ & 354.5 \\
\hline
\end{tabular}

The absorbed solar heat in the collectors can be calculated using Eq. (3) [15]:

$\dot{Q}_{a b s}=G_{b n} F(\cos \theta) L_{c o l} W_{e f f} \varepsilon_{o p t} \gamma$

where $G_{b n}$ is the direct normal irradiance $\left(\mathrm{W} / \mathrm{m}^{2}\right), \theta$ is the angle of incidence, $F(\cos \theta)$ is the incidence modifier function, $L_{c o l}$ is the length of the collector $(\mathrm{m}), W_{\text {eff }}$ is the effective width of the collector $(\mathrm{m}), \varepsilon_{o p t}$ is the optical efficiency, and $\gamma$ is the dirt and broken collectors factor.

The overall heat transfer loss to the environment per unit length is given by Eq. (4):

$\dot{Q}_{a m b}=h_{a m b} A_{a b s, \text { surf }}\left(T_{\text {out }}-T_{\text {in }}\right)$

where the surface area of the collector absorber, $A_{a b s, s u r f}=$ $\pi D_{a b s} L_{c o l}\left(\mathrm{~m}^{2}\right)$, and a constant overall heat transfer coefficient of $h_{a m b}=2.5 \mathrm{~W} / \mathrm{m}^{2} \mathrm{~K}$ (including convection and radiation) are used.
The HTF and the water through the economizer of the steam cycle exchange heat in the solar heat exchanger at a rate given by Eq. (5):

$\dot{m}_{7}\left(h_{3^{\prime}}-h_{3}\right)=h_{H E} A_{H E, \text { surf }}\left(T_{h}-T_{c}\right)$

where $T_{h}$ and $T_{c}$ are the mean temperatures of the HTF and the water $\left({ }^{\circ} \mathrm{C}\right)$, respectively, $A_{H E \text {,surf }}$ is the heat transfer area of the solar heat exchanger $\left(\mathrm{m}^{2}\right)$, and $h_{H E}$ is the overall heat transfer coefficient of the solar heat exchanger $\left(\mathrm{W} / \mathrm{m}^{2}\right.$ $\left.{ }^{\circ} \mathrm{C}\right)$.

The solar heat exchanger has been experimentally characterized in SEGS VI by Eqs. (6) and (7) for the overall heat transfer coefficient and the effectiveness, respectively [15]:

$$
\begin{aligned}
& h_{H E}=\frac{74000}{2}\left(\frac{\dot{V}_{H T F}}{\dot{V}_{H T F, r e f}}+\frac{\dot{m}_{7}}{\dot{m}_{7, \text { ref }}}\right) \\
& \varepsilon=1.025-\frac{0.1}{2}\left(\frac{\dot{V}_{H T F}}{\dot{V}_{H T F, \text { ref }}}+\frac{\dot{m}_{7}}{\dot{m}_{7, \text { ref }}}\right)=\frac{T_{3^{\prime}}-T_{3}}{T_{\text {out }}-T_{3}}
\end{aligned}
$$

where $\dot{V}_{H T F, r e f}\left(\mathrm{~m}^{3} / \mathrm{s}\right)$ and $\dot{m}_{7}(\mathrm{~kg} / \mathrm{s})$ are the reference flow rates of $\mathrm{HTF}$ and water, being equal to $0.624 \mathrm{~m}^{3} / \mathrm{s}$ and $39.3 \mathrm{~kg} / \mathrm{s}$, respectively.

\section{B. Gas Cycle}

The gas cycle consists of three main components: compressor, combustion chamber, and turbine. The compressor takes fresh ambient air and compresses it to higher temperature and pressure. Fuel and high-pressure air from the compressor are sent to the combustion chamber, where the fuel burns at constant pressure, and the resulting high-temperature gases are sent to the turbine. The high-temperature gases expand to the ambient pressure in the turbine and produces power. Finally, the exhaust gases leave the turbine and are sent to the HRSG.

The power of the turbine, $\dot{W}_{G T}(\mathrm{~W})$, and the compressor, $\dot{W}_{\text {comp }}(\mathrm{W})$, can be calculated respectively by Eqs. (8) and (9):

$$
\begin{aligned}
& \dot{W}_{G T}=\dot{m}_{g} c_{p_{g}}\left(T_{3 T}-T_{4 T}\right) \\
& \dot{W}_{\text {comp }}=\dot{m}_{\text {air }} c_{p_{\text {air }}}\left(T_{2 T}-T_{1 T}\right)
\end{aligned}
$$

where $\dot{m}_{g}$ and $\dot{m}_{g}$ are the mass flow rates of the gases and the air $(\mathrm{kg} / \mathrm{s})$, and $c_{p g}$ and $c_{p}$ air are the specific heats at constant pressure for the gases and the air $\left(\mathrm{J} / \mathrm{kg}{ }^{\circ} \mathrm{C}\right)$.

The temperature of the mixture entering the turbine at point 1T, which represents the maximum allowable temperature in the gas cycle, is calculated from Eq. (10), given by the manufacturer, where $T_{1 T}$ and $T_{4 T}$ are in ${ }^{\circ} \mathrm{C}$ and $P_{2 T}$ is in bar:

$T_{1 T}=1.33 T_{4 T}+21.38 P_{2 T}+75.44$

The net power of the gas cycle, $\dot{W}_{G, n e t}$ (W) can be calculated by Eq. (11): 


$$
\dot{W}_{G, n e t}=\dot{W}_{G T}-\dot{W}_{c o m p}
$$

\section{Steam Cycle}

The performance of the steam Rankine cycle based on mass and energy conservation equations has been performed. Eqs. (12)-(15) show the energy balances for the different sections of the HRSG, where mass flow rates are in $\mathrm{kg} / \mathrm{s}$, specific heats at constant pressure are in $\mathrm{J} / \mathrm{kg}$ ${ }^{\circ} \mathrm{C}$, temperatures are in ${ }^{\circ} \mathrm{C}$ and specific enthalpies are in $\mathrm{J} / \mathrm{kg}$ :

$$
\begin{aligned}
& \dot{m}_{g} c_{p_{g}}\left(T_{a}-T_{b}\right)=\dot{m}_{7}\left(h_{7}-h_{5 a}\right) \\
& \dot{m}_{g} c_{p_{g}}\left(T_{b}-T_{c}\right)=\dot{m}_{7}\left(h_{5}-h_{4 a}\right) \\
& \dot{m}_{g} c_{p_{g}}\left(T_{c}-T_{d}\right)=\dot{m}_{7}\left(h_{4}-h_{3^{\prime}}\right) \\
& \dot{m}_{g} c_{p_{g}}\left(T_{d}-T_{e}\right)=\dot{m}_{1}\left(h_{1}-h_{2}\right)
\end{aligned}
$$

The power of the steam turbine, $\dot{W}_{S T}(\mathrm{~W})$, can be calculated through Eq. (16):

$\dot{W}_{S T}=\dot{m}_{7}\left(h_{7}-h_{8}\right)$

The total power for the combined cycle, $\dot{W}_{\text {Total }}(\mathrm{W})$, can be calculated by Eq. (17) as the sum of the power gained from the gas cycle, $\dot{W}_{G, n e t}(\mathrm{~W})$, and the steam turbine, $\dot{W}_{S T}(\mathrm{~W})$ :

$\dot{W}_{\text {Total }}=\dot{W}_{G, \text { net }}+\dot{W}_{S T}$

\section{Results and discussion}

The model is applied for a set of measured data of the direct normal irradiance in Alexandria, Egypt, during four fixed days for each month along the year (day \#1, day $\# 10$, day \#20 \& day \#25), with an interval of 6 minutes. Then average results are taken to present the data for each month.

The control scheme operates the plant under a fuel saving strategy keeping the temperature of the steam at the inlet of the superheater at $441{ }^{\circ} \mathrm{C}$ (manufacturing temperature limit constrain). A HTF storage system is introduced to maximize the benefits from the absorbed solar heat during no sun or nigth periods. The performance limits of the proposed power plant are investigated and the fuel savings with and without the HTF storage system are estimated.

\section{A. Pinch point study}

The pinch point is the temperature difference between the exhaust gases leaving the evaporator section of the HRSG and the saturation temperature of the steam at the drum pressure. The pinch point temperature is usually between $5{ }^{\circ} \mathrm{C}$ and $15{ }^{\circ} \mathrm{C}$ [16]. The pinch point constrains the temperature of the water entering the economizer, $T_{3}$, and consequently the heat rate that can be absorbed in the solar field, $\dot{Q}_{a b s}$. Figure 2 illustrates the relation between the three variables. For this study, all the discussed results are based on a minimum pinch point temperature of $15^{\circ} \mathrm{C}$, for which the heat absorbed by the collectors is $496 \mathrm{~W} / \mathrm{m}$ and the temperature of the water at the inlet of the economizer reaches its maximum of $149^{\circ} \mathrm{C}$.

\section{B. Absorbed, saved and accumulated solar heat}

Figure 3 shows the sequence of operation for the system. Working under the nominal mass flow rate and inlet temperature of the HTF to the collectors defined in Table II, the maximum temperature that the HTF can reach is $150.1^{\circ} \mathrm{C}$ at the maximum solar heat absorbed of 496 $\mathrm{W} / \mathrm{m}$.

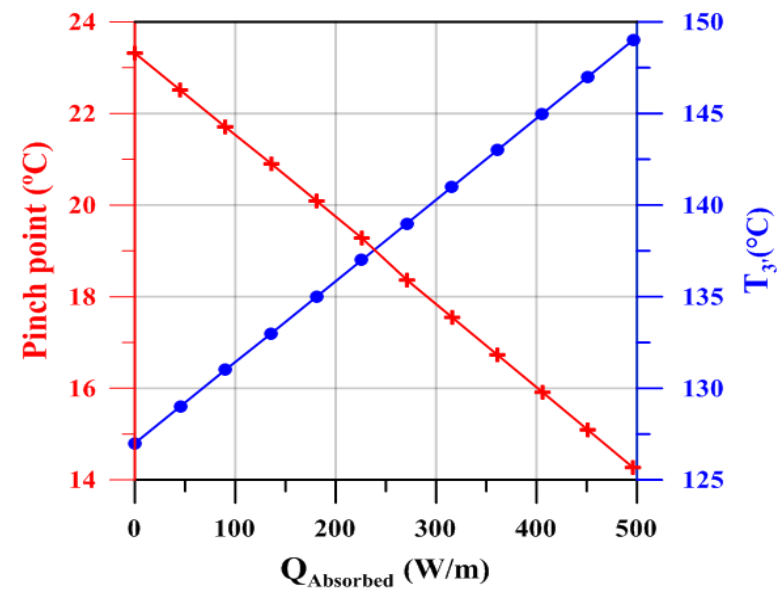

Fig.2. Solar heat absorbed ( $\dot{Q}_{a b s}$ ) vs. Pinch point temperature \& Temperature of water entering the economizer $\left(T_{3}{ }^{\prime}\right)$

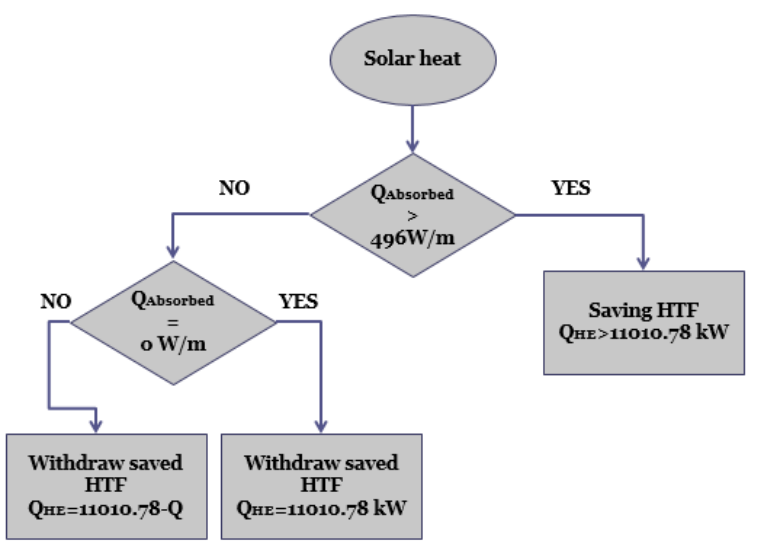

Fig.3. Flow chart for the operation sequence

Therefore, the maximum amount of heat that can be transferred from the HTF to the water in the solar heat exchanger, calculated from Eq. (1), is $11010.78 \mathrm{~kW}$, and the steam plant generates the maximum possible power.

As it can be observed in Fig. 4, from 08:00 to 16:00, the absorbed solar heat exceeds the maximum value for the operation of the steam cycle due to the pinch point temperature constrain. During this period, the extra heat is saved in hot oil and then used during low radiation or night periods. Fig. 5 shows the monthly average heat saved.

The HTF heat storage system operates as follows. If the absorbed heat is higher than the maximum value (496 $\mathrm{W} / \mathrm{m})$, the heat transfer in the heat exchanger is 
maintained constant at its maximum value of 11010.78 $\mathrm{kW}$. Since the outlet temperature of the HTF increases with the absorbed heat, then the oil flow rate through the solar heat exchanger should be modulated, as shown in Fig. 6. The extra oil heated in the collectors is storaged in a very large tank (assuming sink condition) to be used later. If the amount of absorbed heat is lower than the maximum value $(496 \mathrm{~W} / \mathrm{m})$, hot oil from the storage tank is withdrawn to fulfill the maximum value of the water temperature at the inlet of the economizer.

Another parameter studied is the heat accumulated during the month, which is the amount of heat needed for each month during the operation. Figs. 7 and 8 show that during the non-solar hours the required value continue to increase in the negative zone, as there is no heat gained by the solar collector to the power plant. The value starts moving towards the positive zone above the zero line as the sun starts to provide the system with the required heat. Crossing the zero line means that there is extra heat.

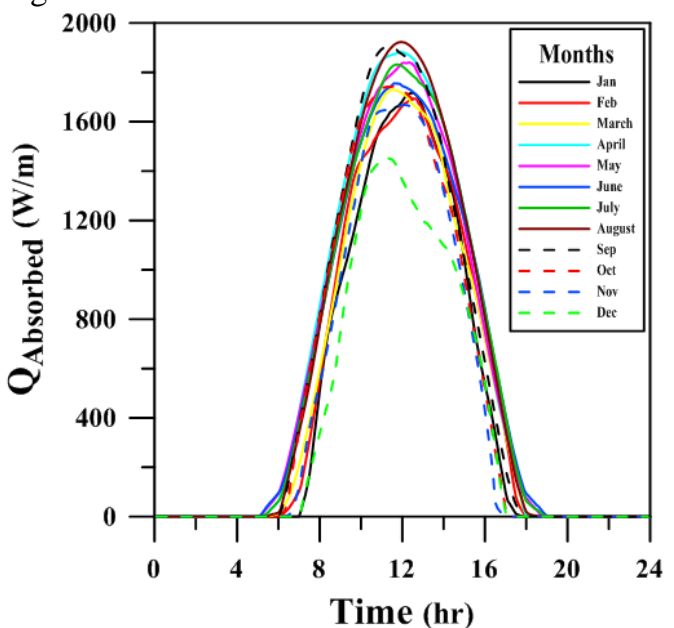

Fig. 4 Monthly average QAbsorbed

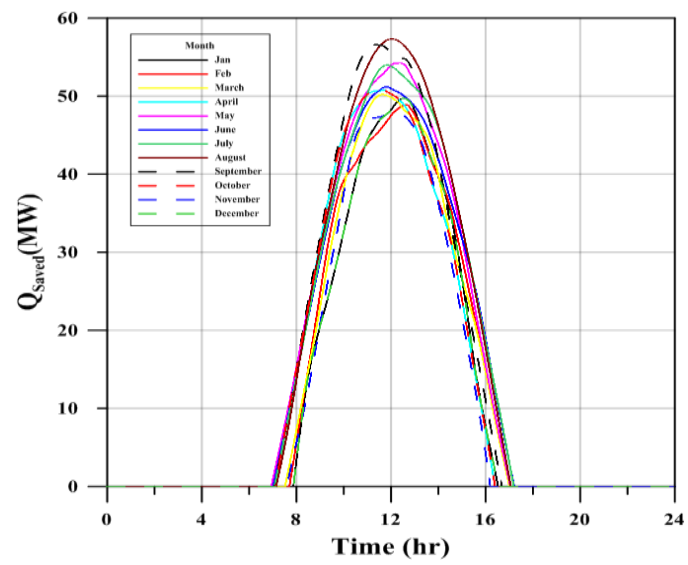

Fig. 5. Monthly average $\dot{Q}_{\text {saved }}$

\section{Fuel and economic savings}

The mass balance in the combustion chamber of the gas turbine allows to calculate the fuel mass flow rate, $\dot{m}_{f}$ $(\mathrm{kg} / \mathrm{s})$, in terms of the gases flow rate and the air to fuel ratio in the gas turbine, $\mathrm{A} / \mathrm{F}$, always equal 50 , according to Eq. (18):

$$
\dot{m}_{g}=\dot{m}_{f}\left(\frac{A}{F}+1\right)
$$

Therefore, the mass flow rate of fuel saved is determined through Eq. (19), in which $\dot{m}_{g, n o m}$ is the nominal gas flow rate, equal to $184.7 \mathrm{~kg} / \mathrm{s}$ :

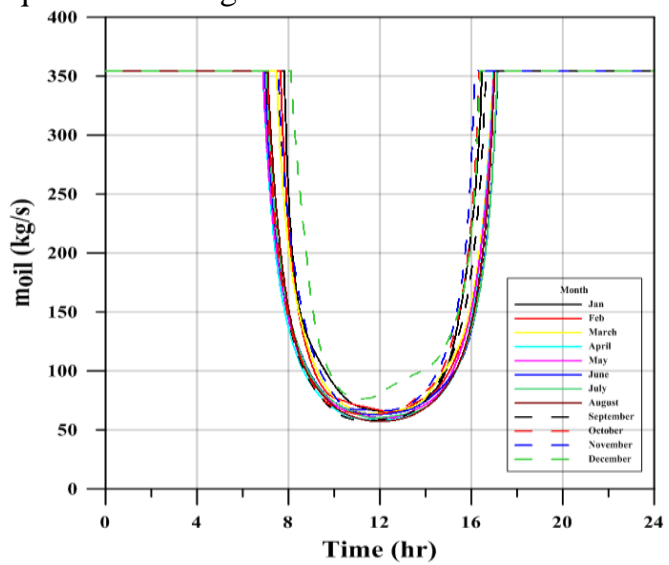

Fig.6. Oil flow rate through the solar heat exchanger

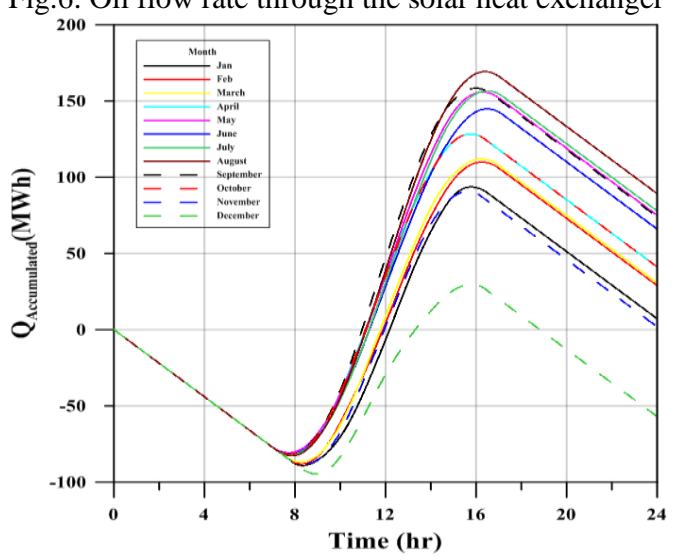

Fig.7 Average daily-accumulated heat required

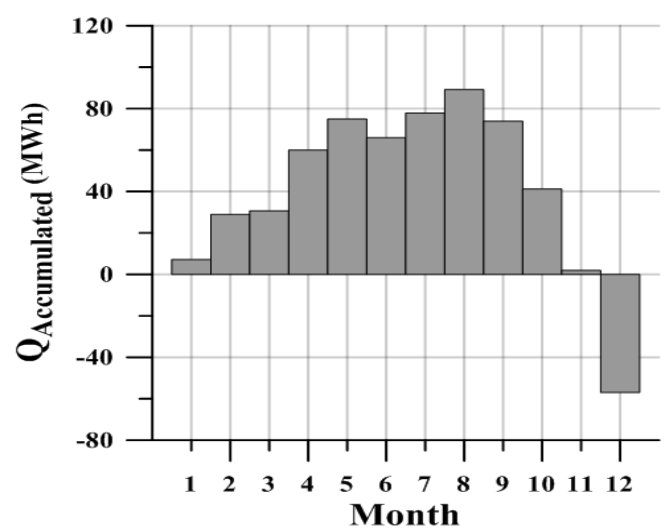

Fig.8 Average monthly-accumulated heat for a year

$$
\Delta \dot{m}_{f, \text { saved }}=\left(\frac{\dot{m}_{g, \text { nom }}-\dot{m}_{g}}{\frac{A}{F}+1}\right)
$$

As shown in Fig. 9, the fuel saving starts from zero when the heat absorbed from sun is $0 \mathrm{~W} / \mathrm{m}$, to the maximum value of $0.06 \mathrm{~kg} / \mathrm{s}$ at the maximum allowable heat absorbed of $496 \mathrm{~W} / \mathrm{m}$. The relation between the fuel saving and the solar heat absorbed is linear, because by increasing the solar heat absorbed a less amount of fuel is used, as heat required in the system decreases. 
Having an HTF storage system is a key factor for the fuel saving process; it ensures working on a full saving capacity for the whole year achieving a maximum saving of fuel. If the system is absorbing maximum solar heat from the sun $(496 \mathrm{~W} / \mathrm{m})$ during the whole year, the fuel saving will reach 5 ton/day. The combined cycle works on a nominal fuel flow rate of 310 ton/day, therefore the total amount of fuel saved would reach $1.65 \%$.

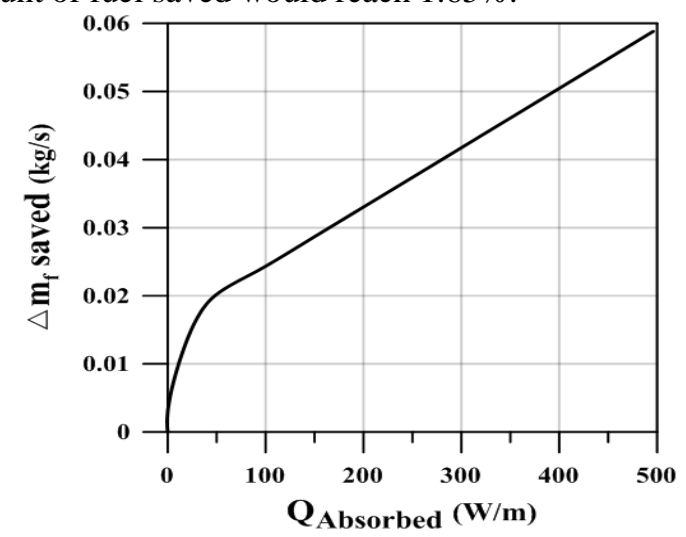

Fig.9. Mass flow rate of fuel saved vs. QAbsorbed

The amount of money that could be saved, knowing that the price of the ton of fuel is assumed to be $242.2 \$$ (4000 LE) [17], is compared in Table III for two situations: with and without considering the HTF storage system. In case of using the HTF storage system, and according to Fig. 8, it can be seen that all months except December can satisfy their needs of heat energy. Consequently, the saving in December is $29,500 \$$, while in the rest of the months the maximum value of $37,000 \$$ is reached, and the annual saving is $436,000 \$$.

Table III. - Monthly and annual money savings with and without the HTF storage system.

\begin{tabular}{|l|c|c|}
\hline Month & With storage (\$) & Without storage (\$) \\
\hline January & 37,000 & 12,096 \\
\hline February & 37,000 & 13,617 \\
\hline March & 37,000 & 13,931 \\
\hline April & 37,000 & 14,859 \\
\hline May & 37,000 & 14,890 \\
\hline June & 37,000 & 15,015 \\
\hline July & 37,000 & 14,906 \\
\hline August & 37,000 & 14,607 \\
\hline September & 37,000 & 14,104 \\
\hline October & 37,000 & 13,601 \\
\hline November & 37,000 & 12,501 \\
\hline December & 29,500 & 11,498 \\
\hline ANNUAL & 436,000 & 165,625 \\
\hline
\end{tabular}

Without the HTF storage system, the money savings depend on the number of hours in which the sun can provide energy more than $496 \mathrm{~W} / \mathrm{m}$ only. It is found that the number of hours differ from month to month, being the minimum in January, with 8.65 hours, and the maximum in June, with 10.19 hours. The anual money saving in this case is $165,625 \$$, that represents $38 \%$ of the money saved during the year by controlling the HTF.

\section{Conclusion}

This study investigates the integration of renewable energy into an existing combined cycle with the objective of reducing the fuel consumption. Maintaining constant the total power output of the combined cycle, the model modulates the fuel, steam and HTF mass flow rates, and calculates the fuel savings compared to the standalone combined cycle under two situations: with and without a HTF storage system. The results show that controlling the mass flow rate of HTF through the solar field can save 436,000 \$, that is $264 \%$ more than that without controlling it $(165,625 \$)$. The fuel savings represent about $1.65 \%$ of the consumption of the combined cycle, and they would be increased if the constraint of the pinch point in the HRSG could be overcomed.

\section{References}

[1] U.S. Energy Information Administration https://www.eia.gov/, last access September 2017.

[2] Union of Concerned Scientists (UCS). 2009. Clean Power Green Jobs.

[3] Global Enery Statistical Yearbook 2019, https://yearbook.enerdata.net/, last access December 2018.

[4] Egyptian Electricity holding company "Annual Report 20142015", http://www.moee.gov.eg/english_new/report.aspx, last access June 2015

[5] Bakos, G. C., and D. Parsa. "Technoeconomic assessment of an integrated solar combined cycle power plant in Greece using line-focus parabolic trough collectors." Renewable energy 60 (2013): 598-603.

[6] Behar, Omar, et al. "Instantaneous performance of the first integrated solar combined cycle system in Algeria." Energy Procedia 6 (2011): 185-193.

[7] Amelio, Mario, et al. "An evaluation of the performance of an integrated solar combined cycle plant provided with air-linear parabolic collectors." Energy 69 (2014): 742-748.

[8]Li, Yuanyuan, and Yongping Yang. "Thermodynamic analysis of a novel integrated solar combined cycle." Applied energy 122 (2014): 133-142.

[9] Li, Yuanyuan, and Yongping Yang. "Impacts of solar multiples on the performance of integrated solar combined cycle systems with two direct steam generation fields." Applied energy 160 (2015): 673-680.

[10] Khaldi, Fouad. "Energy and exergy analysis of the first hybrid solar-gas power plant in Algeria." Ecos (2012): 26-29.

[11] Dersch, Jürgen, et al. "Trough integration into power plants - a study on the performance and economy of integrated solar combined cycle systems." Energy 29.5-6 (2004): 947-959.

[12] Alqahtani, B.J. and Patiño-Echeverri, D., 2016. Integrated Solar Combined Cycle Power Plants: Paving the way for thermal solar. Applied Energy, 169 (2016): 927-936.

[13] Manente, Giovanni. "High performance integrated solar combined cycles with minimum modifications to the combined cycle power plant design." Energy Conversion and Management111 (2016): 186-197.

[14] Ponce, C.V., Sáez, D., Bordons, C. and Núñez, A., 2016. Dynamic simulator and model predictive control of an integrated solar combined cycle plant. Energy, 109 (2016): 974-986.

[15] Stuetzle, T. (2002). Automatic control of a 30 MWe SEGS VI parabolic trough plant ((Master's thesis, University of Wisconsin-Madison, Madison, United states).

[16] Li, You-Rong, Jian-Ning Wang, and Mei-Tang Du. "Influence of coupled pinch point temperature difference and evaporation temperature on performance of organic Rankine cycle." Energy42.1 (2012): 503-509.

[17] Egyptian Ministry of Petroleum

http://www.petroleum.gov.eg/ar/Pages/default.aspx, last access January 2018. 